\title{
Limfocytoza CD4+CD8+ oraz wysięki osierdziowy i opłucnowy u chorego na przewlekłą białaczkę szpikową w fazie przewlekłej leczonego dazatynibem z powodu niepowodzenia terapii imatynibem
}

\author{
CD4+CD8+ lymphocytosis and pleural and pericardiac effusions \\ in a patient with chronic myelogenous leukemia in chronic phase \\ treated with dasatinib due to imatinib failure
}

\author{
Krzysztof Lewandowski, Agata Lehman-Kopydłowska, Michał Gniot, \\ Anna Czyż, Błażej Ratajczak, Mieczysław Komarnicki \\ Katedra i Klinika Hematologii i Transplantacji Szpiku, \\ Uniwersytet Medyczny im. Karola Marcinkowskiego w Poznaniu
}

\begin{abstract}
Streszczenie
Stosowanie inhibitorów kinaz tyrozynowych u chorych na przewlekta biataczke szpikowa (CML) może prowadzić do zmian w uktadzie immunologicznym. W pracy przedstawiono przebieg choroby u pacjenta $w$ fazie przewlektej CML leczonego interferonem $\alpha$, a nastęnie $-z$ powodu utraty więsszej odpowiedzi cytogenetycznej - imatynibem (IM). Po 4 latach leczenia za pomoca IM, mimo uprzedniego uzyskania większej odpowiedzi molekularnej (MMR), potwierdzono utrate catkowitej odpowiedzi cytogenetycznej (oporność mutacyjna, M244V BCR/ABL1). Zastosowanie w kolejnej linii leczenia dazatynibu w dawce $100 \mathrm{mg} /$ dobe pozwolito na uzyskanie gtębokiej odpowiedzi molekularnej (DMR). W trakcie pierwszych 9 miesiecy terapii tolerancja leczenia byta dobra. Później pojawity sie objawy ogólne (stany podgoraczkowe, nadmierne poty), nieżyt btony śluzowej nosa, a we krwi obwodowej - leukocytoza z bezwzgledna limfocytoza CD3+, CD8+, HLA-DR+. Po 2 latach, z powodu nasilenia się wyżej wymienionych dolegliwości, dawkę leku zmniejszono do $80 \mathrm{mg} /$ dobę. Przyniosto to ustapienie wymienionych dolegliwości oraz normalizacje liczby leuko- $i$ limfocytów we krwi. Zmniejszenie dawki leku doprowadzito jednak do utraty MMR. Powrót do wyjściowej dawki dazatynibu pozwolit ponownie uzyskać DMR. Poprawie jakości odpowiedzi molekularnej towarzyszyt nawrót dolegliwości ogólnych oraz ponowny wzrost limfocytozy we krwi. Po kilku miesiqcach leczenia dazatynibem wystapity wymagajace hospitalizacji objawy wysiekowego zapalenia optucnej i osierdzia. Po ustabilizowaniu stanu chorego zdecydowano o zastosowaniu nilotynibu. $W$ trakcie 12-miesiecznego okresu obserwacji tolerancja leczenia byta dobra. Stosowanie nilotynibu doprowadzito do szybkiego ustapienia objawów ogólnych oraz limfocytozy, a także ponownego uzyskania DMR.
\end{abstract}

Słowa kluczowe: przewlekła białaczka szpikowa, dazatynib, limfocytoza, duże ziarniste limfocyty

Hematologia 2015; 6, 3: 301-307

Adres do korespondencji: Krzysztof Lewandowski, Katedra i Klinika Hematologii i Transplantacji Szpiku, Uniwersytet Medyczny im. Karola Marcinkowskiego, ul. Szamarzewskiego 84, 60-569 Poznań, tel. 618549383 ; faks 6185493 56, e-mail: krzysztof.lewandowski@skpp.edu.pl 


\begin{abstract}
Using tyrosine kinase inhibitors in chronic myelogenous leukemia (CML) patients may have resulted in abnormalities of the immune system. The paper is showing disease outcome in a patient with CML in chronic phase treated with interpheron $\alpha$, and thereafter with imatinib (IM) due to loss of major cytogenetic response. After 4 years of IM treatment, despite previous major molecular response (MMR) obtained, loss of complete cytogenetic response was documented (mutational resistance, M244V BCR/ABL1). Administering $100 \mathrm{mg}$ dasatinib daily in consecutive treatment line allowed obtaining deep molecular response (DMR). During initial 9 months of the treatment, tolerance was good. Thereafter, the general symptoms could be observed (subfebrile states, excessive sweets), rhinitis and leukocytosis with absolute lymphocytosis CD3+, CD8+, HLA-DR in the peripheral blood. After two years, due to an increase in symptoms intensity, the dose of the drug was reduced to $80 \mathrm{mg}$ daily. It was related with symptoms release and normalization of leuko- and lymphocyte count in the blood. Drug dose reduction, however, resulted in loss of MMR. Increasing the dose to the initial one allowed re-obtaining DMR. Improvement in molecular response quality was associated with reccurrence of general symptoms and lymphocytosis in the peripheral blood. After a few months, pleural/pericardial effusion symptoms were noted. Patient required hospitalization and therapeutic paracentesis. After normalization of the general patient status, the decision about nilotinib treatment was taken. During 12 months follow-up, the drug tolerance was good. Nilotinib treatment resulted in fast disappearance of general symptoms and lymphocytosis, and achievement of DMR.
\end{abstract} Keywords: chronic myelogenous leukemia, dasatinib, lymphocytosis, large granular
lymphocytes

Hematologia 2015; 6, 3: 301-307

\section{Wprowadzenie}

Przewlekła białaczka szpikowa (CML, chronic myelogenous leukemia) jest chorobą komórki macierzystej szpiku, należącą — według klasyfikacji Światowej Organizacji Zdrowia (WHO, World Health Organization) z 2008 roku - do nowotworów mieloproliferacyjnych (MPN, myeloproliferative neoplasms). Wystąpienie CML wiąże się z nabyciem przez pojedynczą komórkę pluripotrencjalną szpiku translokacji $\mathrm{t}(9,22)$, co skutkuje powstaniem genu fuzji $B C R / A B L 1$ kodującego sekwencję onkogennej kinazy tyrozynowej BCR/ABL1. Jej konstytutywna, wysoka aktywność w komórkach potomnych prowadzi do ich niekontrolowanej proliferacji, zakłócenia procesów apoptozy, adhezji komórkowej, a także niestabilności genomowej. $W$ przypadkach nieleczonych choroba ewoluuje $z$ fazy przewlekłej do faz bardziej zaawansowanych - akceleracji i kryzy blastycznej. Jeszcze 10 lat temu rokowanie w tej grupie chorych było niekorzystne, a jedyną możliwością wyleczenia i przedłużenia przeżycia było przeszczepienie krwiotwórczych komórek macierzystych $\mathrm{w}$ przypadkach $\mathrm{z}$ dostępnym zgodnym dawcą rodzinnym lub niespokrewnionym. Wprowadzenie do leczenia inhibitorów kinazy tyrozynowej (TKI, tyrosine kinase inhibitors), zarówno I generacji — tj. imatynibu (IM), jak i II generacji - tj. nilotynibu (NILO) i dazatynibu (DAZA), całkowicie zrewolucjonizowało podejście terapeutyczne do tej choroby. Mechanizm działania IM i NILO polega na zahamowaniu autofosforylacji kinazy BCR/ABL1 i fosforylacji substratów. Prowadzi to do wygaszenia proliferacji komórek oraz indukcji procesów ich apoptozy. Spektrum działania hamującego wymienionych TKI obejmuje także inne kinazy tyrozynowe - ABL1, c-KIT i receptora dla płytkopochodnego czynnika wzrostu (PDGFR, platelet-derived growth factor receptor). Należy jednak dodać, że efekt inhibitorowy w odniesieniu do kinazy BCR/ABL1 w przypadku NILO jest około 30-krotnie silniejszy niż w przypadku IM [1]. Szerszym spektrum działania inhibitorowego charakteryzuje się DAZA. Jest on około 325 razy silniejszym od IM inhibitorem kinazy ABL1. Hamuje także między innymi aktywność c-KIT, PDGFR oraz kinaz $z$ rodziny SRC (głównych regulatorów odpowiedzi immunologicznej) [2, 3]. Ostatnio zwrócono uwagę na związek między stosowaniem określonego rodzaju TKI a występowaniem zaburzeń funkcji układu immunologicznego. Stwierdzono, że u chorych leczonych IM dochodzi do hipogammaglobulinemii i obniżenia stężenia immunoglobulin [4], upośledzenia funkcji komórek naturalnej cy- 
totoksyczności (NK, natural killers) [5], a także regulatorowych oraz efektorowych komórek T [6]. W warunkach in vitro IM indukuje wzrost plazmocytoidalnych komórek dendrytycznych i hamuje różnicowanie ludzkich progenitorowych komórek CD34(+) w kierunku komórek dendrytycznych $[7,8]$. Obniżoną proliferację i obecność zaburzeń czynności limfocytów T CD8+ potwierdzono natomiast u chorych leczonych NILO [9]. W warunkach in vitro wykazano, że DAZA upośledza funkcję prawidłowych limfocytów T, głównie w wyniku hamowania kinazy tyrozynowej Btk $[10,11]$. W wyniku ekspozycji na lek dochodzi także do zahamowania, specyficznych dla określonego antygenu, funkcji efektorowych limfocytów T [12], a także klonalnej ekspansji dużych, ziarnistych limfocytów [13]. Wystąpienie wyżej wymienionych zmian immunologicznych może zmieniać przebieg kliniczny chorych na CML leczonych poszczególnymi TKI.

\section{Opis przypadku}

Chory $\mathrm{w}$ wieku 58 lat $\mathrm{z}$ rozpoznaniem CML, ustalonym w lutym 2001 roku (wskaźnik Sokala 0,18 ), w latach 2001-2003 był leczony interferonem a $(\mathrm{IFN} \alpha)$ - początkowo w dawce $5 \mathrm{mln} \mathrm{jm} . / \mathrm{m}^{2}$, a po uzyskaniu remisji hematologicznej ( $\mathrm{HR}$, he-

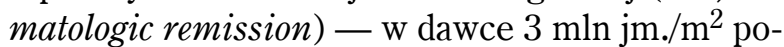
dawanej 3 razy $\mathrm{w}$ tygodniu. $\mathrm{W}$ ocenie klinicznej, przeprowadzonej w listopadzie 2003 roku, stwierdzono utratę uzyskanej po 2 latach terapii większej odpowiedzi cytogenetycznej (MCyR, major cytogenetic remission) $25 \%$ metafaz $\mathrm{z}$ translokacja $\mathrm{t}(9,22)$ (q34;q11), przy zachowanej całkowitej remisji hematologicznej (CHR, complete hematologic remission). $Z$ tego powodu, w grudniu 2003 roku, chorego zakwalifikowano do leczenia IM w dawce $400 \mathrm{mg} /$ dobę, doustnie. Całkowitą remisję cytogenetyczną (CCyR, complete cytogenetic remission) uzyskano dopiero po 34 miesiącach stosowania leku, a większą odpowiedź molekularną (MMR, major molecular remission) - 10 miesięcy później, tj. w październiku 2007 roku. W styczniu 2011 roku, $z$ powodu utraty MMR (BCR/ABL1 IS $2,4919 \%)$ oraz CCyR (obecność fuzji $B C R / A B L 1$ stwierdzona metodą fluorescencyjnej hybrydyzacji in situ [FISH, fluorescence in situ hybridization] w $73 \%$ $Z$ analizowanych 250 jąder interfazowych), przy zachowanej CHR, zdecydowano o zastosowaniu terapii II linii — DAZA (Sprycel ${ }^{\circledR}$, Bristol-Myers-Squibb) w dawce $100 \mathrm{mg} \mathrm{raz} /$ dobę, doustnie. Retrospektywna analiza próbek wyizolowanego RNA wykazała obecność mutacji M244V (umiarkowana wrażliwość na IM) już w czerwcu 2009 roku.
Zastosowanie leku pozwoliło na uzyskanie CCyR (46XY [35]) i głębokiej odpowiedzi molekularnej (DMR, deep molecular remission); ilość transkryptu $B C R / A B L 1$ p210 przy czułości stosowanej metody pomiaru na poziomie $\mathrm{MR}^{4,5}$. W trakcie pierwszych 9 miesięcy leczenia tolerancja leku była bardzo dobra. W listopadzie 2011 roku wystąpiły jednak okresowe stany podgorączkowe, potliwość nocna oraz nawracające nieżyty błony śluzowej nosa. W morfologii krwi potwierdzono leukocytozę $(11,2-14,0 \mathrm{G} / \mathrm{l}) \mathrm{z}$ bezwzględną limfocytozą $(7,2-10,3 \mathrm{G} / 1)$. W tym okresie w badaniu przedmiotowym nie stwierdzano limfadenopatii ani hepatosplenomegalii, a w badaniach obrazowych (badanie radiologiczne [RTG] klatki piersiowej, badania ultrasonograficzne [USG] jamy brzusznej) - powiększenia węzłów chłonnych, wątroby czy śledziony. W rozmazie krwi obwodowej widoczne były duże ziarniste limfocyty (ryc. 1). Analiza cytometryczna leukocytów krwi obwodowej wykazała limfocytozę z komórek T - CD3+, CD8+, HLA-DR +. Nie stwierdzono obecności rearanżacji monoklonalnej $(\gamma, \delta)$ genu $T C R-G$ w badaniu molekularnym limfocytów krwi obwodowej. Stan ten utrzymywał się przez 23 miesiące obserwacji ambulatoryjnej (od listopada 2011 do grudnia 2013 r,). W kwietniu 2013 roku, $z$ powodu utrzymywania się nasilonych objawów ogólnych oraz bólów mięśniowych, dawkę DAZA zmniejszono do $80 \mathrm{mg} /$ dobę. W kolejnych miesięcach obserwacji (maj-lipiec 2013 r.) odnotowano zmniejszenie nasilenia objawów ogólnych oraz ustąpienie dolegliwości mięśniowych. Normalizacji uległa także liczba leukoi limfocytów we krwi obwodowej. Zmniejszenie dawki leku doprowadziło jednak do utraty MMR, którą ponownie uzyskano po zwiększeniu dawki DAZA do $100 \mathrm{mg}$ /dobę (ryc. 2).

Poprawie jakości odpowiedzi molekularnej towarzyszył nawrót objawów klinicznych (temp. ciała ok. $37^{\circ} \mathrm{C}$, poty nocne, nieżyt błony śluzowej nosa) oraz ponowne pojawienie się limfocytozy (liczba krwinek białych 10,91-17,57 G/1, liczba limfocytów 9,71-13,0 G/1). Ze względu na nieduże nasilenie dolegliwości oraz ponowne uzyskanie DMR (październik 2013 r.) leczenie kontynuowano. W styczniu 2014 roku chory zgłosił nasiloną duszność. Badanie przedmiotowe wykazało stłumienie odgłosu opukowego nad polem płucnym po prawej stronie (ok. $5 \mathrm{~cm}$ od podstawy płuca w linii łopatkowej), a badanie RTG klatki piersiowej — niedodmę środkowego i dolnego płata prawego pluca oraz obecność znacznej ilości płynu w prawej jamie opłucnej (VII przestrzeń międzyżebrowa, II/III stopień wg CTCAE [Common Terminology Criteria 
Hematologia 2015, tom 6, nr 3

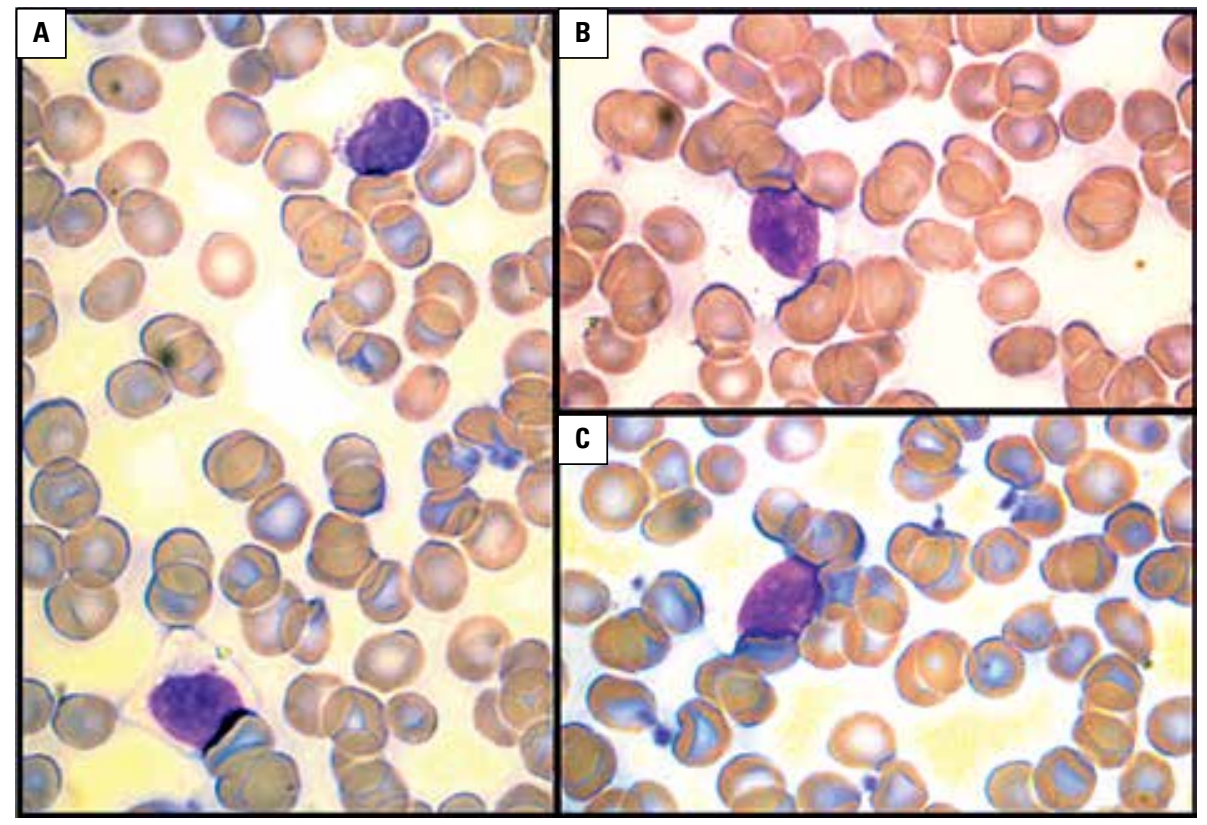

Rycina 1A-C. Pacjent WW; duże ziarniste limfocyty w rozmazie krwi obwodowej

Figure 1A-C. Patient WW; large granular lymphocytes in peripheral blood smears

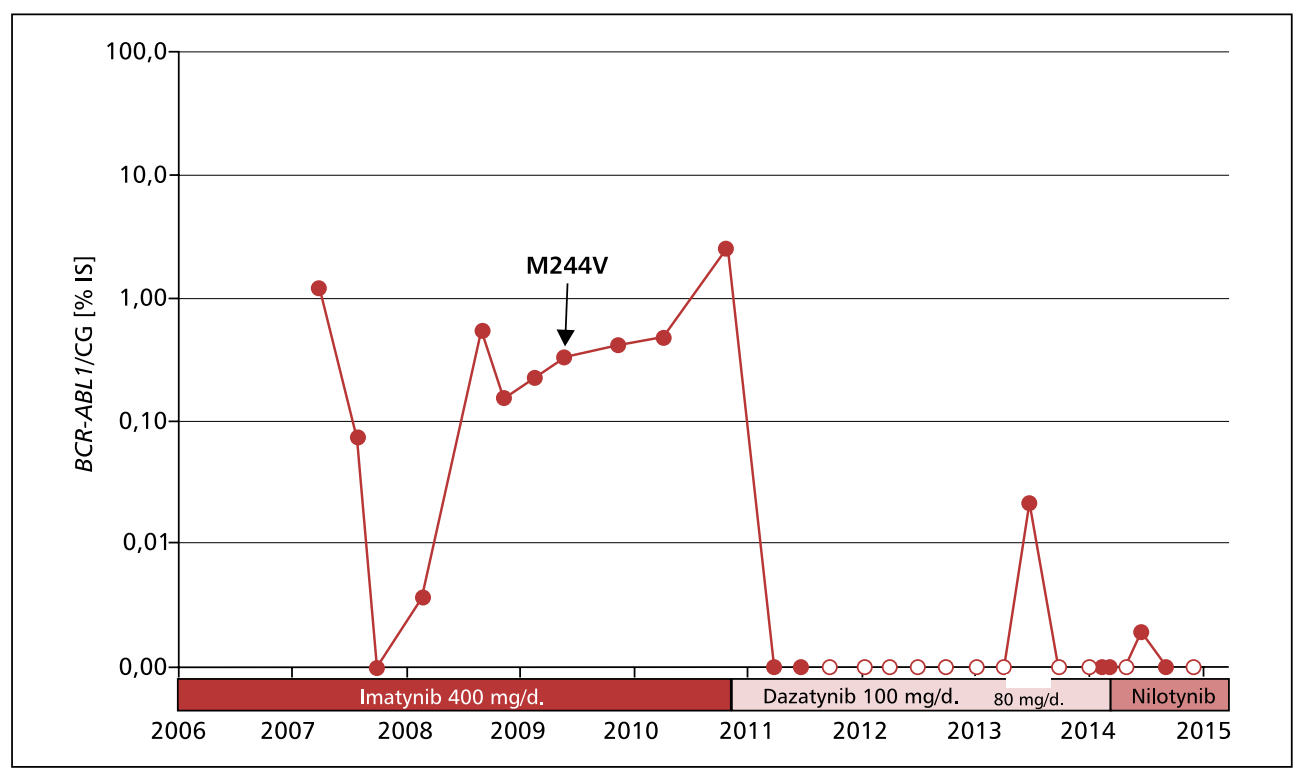

Rycina 2. Pacjent WW; ocena odpowiedzi molekularnej w trakcie leczenia inhibitorami kinazy tyrozynowej w badaniach jakościowym i ilościowym; ○ ujemny wynik badania nested-RT-PCR; • dodatni wynik badania nested-RT-PCR; RT-PCR — reakcja łańcuchowa polimerazy odwrotnej transkryptazy

Figure 2. Patient WW, the molecular response during the tyrosine kinase inhibitor treatment; $\bigcirc$ nested-RT-PCR negative; $\bullet$ nested RT-PCR positive; RT-PCR — reverse transcriptase-polymerase chain reaction

for Adverse Events]). Badanie echokardiograficzne wykazało obecność płynu w osierdziu (II stopień wg CTCAE). $Z$ powodu duszności pacjenta hospitalizo- wano. Dwukrotnie wykonano paracentezę, ewakuując płyn o charakterze wysiękowym. Zastosowano także leczenie objawowe steroidami (prednizon 
$20 \mathrm{mg} \mathrm{raz} / \mathrm{d}$.) oraz diuretykami pętlowymi (furosemid $40 \mathrm{mg} \mathrm{raz} /$ d.) [14]. Po ustabilizowaniu stanu klinicznego chorego, w styczniu 2014 roku, wdrożono terapię za pomocą NILO (Tasigna ${ }^{\circledR}$, Novartis) w dawce 2 razy $400 \mathrm{mg} /$ dobę. Jeszcze w tym samym miesiącu zaobserwowano całkowite ustąpienie objawów ogólnych, leukocytozy $(7,48 \mathrm{G} / 1)$, a także zmniejszenie liczby limfocytów we krwi (3,5 G/1). Tomografia komputerowa narządów klatki piersiowej potwierdziła całkowite ustąpienie wysięku opłucnowego i osierdziowego. W maju 2014 roku wykonano kontrolną analizę cytometryczną leukocytów krwi obwodowej, która nie potwierdziła obecności limfocytozy T CD3+, CD8+ HLA-DR+. Także stosunek ilości limfocytów CD4+ do CD8+ był prawidłowy.

W trakcie trwającej 12 miesięcy terapii tolerancja leczenia za pomocą NILO była dobra. Nie obserwowano także nawrotu leuko- i limfocytozy, a regularnie prowadzona kontrola laboratoryjna potwierdzała utrzymywanie się $\mathrm{MR}^{4,5}(B C R / A B L 1$ IS $0,0020 \%)$.

\section{Dyskusja}

Leczenie za pomocą TKI w większości przypadków CML jest dobrze tolerowane. Do najczęstszych, niehematologicznych działań niepożądanych, obserwowanych u chorych otrzymujących IM, należą: nudności, biegunki, obrzęki (głównie twarzy i wokół oczu), bóle mięśniowe, zwiększenie masy ciała. Nieco rzadziej występują skórne wysypki plamisto-grudkowe oraz obrzęki uogólnione. Stosowanie IM prowadzi u części chorych do wystąpienia objawów toksyczności hematologicznej, objawiającej się 1-, 2- lub 3-układową cytopenią. Wyniki oceny 8 lat terapii chorych uczestniczących w badaniu IRIS (Imatinib Therapy for Patients with Chronic Myelogenous Leukemia) potwierdzily, że $z$ powodu nietolerancji/nieskuteczności IM leczenie należy przerwać u $22 \%$ chorych [15]. Tolerancja leczenia NILO w II linii terapii CML u chorych $\mathrm{z}$ objawami nietolerancji/nieskuteczności IM również jest dobra. U części $z$ nich dochodzi do wzrostu stężenia bilirubiny we krwi, aktywności aminotransferaz, lipazy lub/i amylazy trzustkowej oraz dyslipidemii. Rzadko objawy te mają nasilenie 3.-4. stopnia według WHO. U niewielkiego odsetka chorych obserwuje się występowanie objawów toksyczności kardiologicznej leku (wydłużenie odcinka QT w zapisie EKG) lub choroby niedokrwiennej tętnic obwodowych. Hematologiczne działania niepożądane, w tym granulocytopenia, małopłytkowość czy anemia, są również typowe i wystę- pują u części pacjentów [16]. W przypadku DAZA najpoważniejszym, ale rzadkim powikłaniem jest pojawienie się nadciśnienia płucnego lub/i wysięku opłucnowego/osierdziowego. Stosowanie leku może także prowadzić do wystąpienia objawów toksyczności hematologicznej (niedokrwistość, granulocytopenia/małopłytkowość). W tym ostatnim przypadku ryzyko krwawień jest zwiększone $z$ uwagi na antyagregacyjne działanie leku [17]. $Z$ tego powodu w przypadku chorych leczonych DAZA zalecana jest duża ostrożność podczas kwalifikacji do leczenia środkami hamującymi funkcję płytek krwi lub przeciwkrzepliwymi $z$ innych powodów. Do innych objawów niepożądanych związanych ze stosowaniem leku należą: uczucie zmęczenia, anoreksja, bóle brzucha, mięśni głowy, dyselektrolitemia (hipokalcemia i hipofosfatemia), przejściowy wzrost stężenia kreatyniny we krwi. Geneza wysięków osierdziowo-opłucnowych u pacjentów leczonych DAZA nie jest do końca poznana. Jedną $z$ przyczyn może być zależne od leku zahamowanie funkcji limfocytów T regulatorowych, a poprzez to - indukcja procesów autoimmunizacyjnych. Innym rzadkim powikłaniem leczenia DAZA jest limfocytoza we krwi obwodowej.

W prezentowanym przypadku, $z$ powodu utraty MMR i CCyR w trakcie leczenia IM, podjęto decyzję o zmianie leczenia na DAZA. W trakcie stosowania leku w dawce $100 \mathrm{mg} /$ dobę zaobserwowano wzrost bezwzględnej liczby limfocytów $\mathrm{CD} 3+, \mathrm{CD} 8+$ we krwi, a także okresowe występowanie objawów ogólnych, takich jak stany podgorączkowe, poty nocne oraz nawracające nieżyty błony śluzowej nosa. Wymienione dolegliwości podmiotowe ustąpiły po zmniejszeniu dobowej dawki leku do $80 \mathrm{mg}$. Co ciekawe, do ich pojawienia się doszło ponownie po 2 miesiącach, $z$ chwilą powrotu do dawki $100 \mathrm{mg}$ /dobę. Mimo dobrej odpowiedzi molekularnej leczenie DAZA wstrzymano Z powodu obustronnego wysięku opłucnowego, wymagającego 2-krotnego odbarczenia w warunkach szpitalnych. Rozpoznano nietolerancję DAZA i zdecydowano o dalszej terapii za pomocą NILO w dawce 2 razy $400 \mathrm{mg} /$ dobę. W trakcie stosowania leku odnotowano ustapienie limfocytozy we krwi oraz całkowite ustąpienie uprzednio obserwowanych objawów ogólnych. W kolejnych miesiącach regularnie prowadzona kontrola molekularna potwierdziła utrzymywanie się DMR.

W 2009 roku po raz pierwszy przedstawiono dane dotyczące wpływu DAZA na obecność dużych, ziarnistych limfocytów (LGL, large granular lymphocyte) we krwi chorych na CML. W 2009 roku Mustjoki i wsp. [18] potwierdzili wzrost liczby 
limfocytów o morfologii LGL we krwi 22 chorych leczonych DAZA. Wykazywały one immunofenotyp efektorowych komórek pamięci T (CD3+, CD8+) lub komórek NK (CD3-, CD16/CD56+). Praktyczne znaczenie tej obserwacji nie jest do końca poznane. Okazało się jednak, że czas przeżycia chorych leczonych DAZA, u których doszło do wzrostu zawartości LGL we krwi, był dłuższy niż chorych bez tego powikłania [18]. Podobne obserwacje poczynili Kim i wsp. [19] w 2009 roku na podstawie analizy bezwzględnej liczby limfocytów we krwi u 8 spośród 18 chorych leczonych DAZA. Także w tym doniesieniu odpowiedź molekularna na leczenie DAZA w przypadkach przebiegających $z$ limfocytozą była optymalna [19]. Również przebieg kliniczny choroby w prezentowanym przypadku potwierdza związek między wystąpieniem limfocytozy a uzyskaniem i utrzymywaniem się DMR (35 miesięcy).

Etiopatogeneza obserwowanych powikłań (limfocytozy CD3+, CD8 + oraz wysięku opłucnego) nie jest do końca poznana. U nieleczonych chorych na CML wykazano obecność klonalnej populacji limfocytów o fenotypie T lub/i komórek NK. Nie zawsze mają one jednak charakter monoklonalny) [20]. Zauważono, że ich zawartość we krwi zwiększa się w trakcie pierwszych 1-9 miesięcy leczenia za pomocą DAZA (w prezentowanym przypadku po 9 miesiącach). W jednej $z$ ostatnich analiz oceniono, że wzrost we krwi liczby limfocytów o morfologii LGL dotyczy 30-60\% chorych. Występowanie podobnego zjawiska zaobserwowano u chorych na ostrą białaczką limfoblastyczną (ALL, acute lymphoblastic leukemia) z obecnym chromosomem Filadelfia (Ph, Philadelphia) [18, 20-22].

W roku 2009 opisano pierwsze przypadki limfocytozy LGL u chorych w fazie przewlekłej CML leczonych DAZA $[18,19]$. Rok później analiza przeprowadzona $\mathrm{w}$ większej grupie chorych $\mathrm{w}$ fazie przewlekłej CML leczonych DAZA w I linii terapii potwierdziła występowanie limfocytozy (nie tylko z LGL) u 28\% (185/662) z nich. Efekt ten okazał się niezależny od dobowej dawki stosowanego leku, a także sposobu jego podawania (raz/d., 2 razy/d.) [23]. W 2011 roku opisano wzrost bezwzględnej limfocytozy we krwi u 23 spośród 50 pacjentów $z 9$ koreańskich ośrodków hematologicznych oraz u 4 spośród 15 chorych $z$ Detroit, leczonych DAZA $z$ powodu CML $[24,25]$. Wystapienie podobnego zdarzenia odnotowano także u 1 spośród 18 (5,5\%) pacjentów leczonych DAZA w ośrodku autorów niniejszej pracy.

Etiopatogeneza limfocytozy u chorych na CML leczonych DAZA nie jest znana. Być może, u części chorych stosowanie DAZA prowadzi do ekspan- sji obecnego przed leczeniem klonu limfocytów w wyniku zależnej od leku stymulacji ich wzrostu. Ostatnio wykazano, że podanie DAZA prowadzi do szybkiej, zależnej od dawki i znaczącej mobilizacji niebiałaczkowych limfocytów i monocytów do krwi. Efekt ten jest osiagany maksymalnie 2 godziny po podaniu i w zasadzie odzwierciedla wzrost jego stężenia w osoczu. Preferencyjnie mobilizacji podlegają komórki NK, NK T, limfocyty B oraz komórki T $\gamma \delta+[26]$. Wiadomo bowiem, że DAZA jest silnym inhibitorem kinaz z rodziny SRC, istotnych dla procesów odpowiedzi immunologicznej $[3,25]$. Trudna do wytłumaczenia jest również obserwacja wskazująca, że do wzrostu bezwzględnej liczby limfocytów dochodzi w wyniku pojawienia się zwiększonej liczby ich różnych subpopulacji (LGL, NK, limfocyty T). Być może, w patogenezie tego zjawiska uczestniczą też inne czynniki modyfikujące efekt końcowy stosowanego leku. W jednym $z$ doniesień Mustjoki i wsp. [23] sugerują rolę obecności antygenu zgodności tkankowej HLA*0201 oraz udział w patogenezie limfocytozy $\mathrm{u}$ chorych na CML reaktywacji infekcji wirusem cytomegalii (CMV, cytomegalovirus).

Ostatnio Matsushita i wsp. [27] przedstawili przypadek chorego na ALL Ph + ze wznową choroby po uprzednim leczeniu za pomocą chemioterapii, IM oraz uzyskaniu całkowitej remisji molekularnej (CMR, complete molecular remission) choroby $\mathrm{w}$ wyniku przeszczepienia allogenicznych krwiotwórczych komórek macierzystych (allo-HSCT, allogeneic hematopoietic stem cell transplantation). Podanie DAZA w dawce $100 \mathrm{mg} /$ dobę w tym przypadku doprowadziło do ponownego uzyskania CMR po miesiącu leczenia. $Z$ powodu wystąpienia wysięku oplucnowego oraz toksyczności wątrobowej 1. stopnia dawkę leku zmniejszono do $70 \mathrm{mg} /$ dobę, co pozwoliło na utrzymanie CMR przez kolejne 7 miesięcy dalszej obserwacji. Dziesięć dni po inicjacji terapii we krwi zaobserwowano wzrost odsetka LGL (10-30\%). Większość z nich stanowiły limfocyty T CD3+, a niewielką część - komórki NK (odpowiednio $70,6 \%$ oraz $11,3 \%$ ). Analiza ekspresji antygenów CD4 i CD8 potwierdziła, że w populacji limfocytów T CD3 dominowały komórki CD8+ (odpowiednio 50,4\% i 16,8\%). Okazało się także, że większość komórek CD8+ cechuje koekspresja CD57 i że komórki te charakteryzuje fenotyp efektorowych komórek pamięci (CD45RA-, CD62L-). W prezentowanym przypadku potwierdzono także niską liczbę limfocytów T regulatorowych o fenotypie CD4+ CD25+ FoxP3+, co jest zgodne $z$ poprzednimi doniesieniami dotyczącymi wpływu stosowania DAZA na liczbę limfocytów T 
regulatorowych [27]. Wystąpienie wymienionych zmian immunologicznych może mieć istotny wpływ na szybkość uzyskiwania odpowiedzi cytogenetycznej i molekularnej. Hipoteza ta wymaga jednak dalszych badań. Wiadomo jednak, że całkowity czas przeżycia chorych, u których w trakcie terapii DAZA doszło do wzrostu bezwzględnej liczby limfocytów we krwi, jest dłuższy niż pacjentów, u których takie zdarzenie nie nastąpiło [18, 25].

\section{Podsumowanie}

Przebieg leczenia w prezentowanym przypadku potwierdza, jak ważnym elementem składowym opieki medycznej nad chorym na CML jest kontrola kliniczna i laboratoryjna. Umożliwia ona zmianę terapii/zmniejszenie dawki stosowanego leku w przypadku stwierdzenia obecności objawów niepożądanych. Optymalizacja procesu leczenia chorych na CML wymaga także dogłębnej wiedzy na temat wszystkich aspektów działania stosowanego leku.

\section{Piśmiennictwo}

1. Weisberg E., Manley P.W., Breitenstein W. i wsp. Characterization of AMN107, a selective inhibitor of native and mutant Bcr-Abl. Cancer Cell. 2005; 7: 129-141.

2. Shah N.P., Tran C., Lee F.Y. i wsp. Overriding imatinib resistance with a novel ABL kinase inhibitor. Science 2004; 305: 399-401.

3. Rix U., Hantschel O., Dürnberger G. i wsp. Chemical proteomic profiles of the BCR-ABL inhibitors imatinib, nilotinib, and dasatinib reveal novel kinase and nonkinase targets. Blood 2007; 110: 4055-4063.

4. Steegmann J.L., Moreno G., Aláez C. i wsp. Chronic myeloid leukemia patients resistant to or intolerant of interferon alpha and subsequently treated with imatinib show reduced immunoglobulin levels and hypogammaglobulinemia. Haematologica 2003; 88: 762-768.

5. Cwynarski K., Laylor R., Macchiarulo E. i wsp. Imatinib inhibits the activation and proliferation of normal T lymphocytes in vitro. Leukemia 2004; 18: 1332-1339.

6. Appel S., Balabanov S., Brümmendorf T.H., Brossart P. Effects of imatinib on normal hematopoiesis and immune activation. Stem Cells 2005; 23: 1082-1088.

7. Mohty M., Jourdan E., Mami N.B. i wsp. Imatinib and plasmacytoid dendritic cell function in patients with chronic myeloid leukemia. Blood 2004; 103: 4666-4668.

8. Appel S., Rupf A., Weck M.M. i wsp. Effects of imatinib on monocyte-derived dendritic cells are mediated by inhibition of nuclear factor-kappaB and Akt signaling pathways. Clin. Cancer Res. J. Am. Assoc. Cancer Res. 2005; 11: 1928-1940.

9. Chen J., Schmitt A., Chen B. i wsp. Nilotinib hampers the proliferation and function of CD8 + T lymphocytes through inhibition of T cell receptor signalling. J. Cell. Mol. Med. 2008; 12: 2107-2118.

10. Blake S., Hughes T.P., Mayrhofer G., Lyons A.B. The Src/ABL kinase inhibitor dasatinib (BMS-354825) inhibits function of normal human T-lymphocytes in vitro. Clin. Immunol. Orlando Fla. 2008; 127: 330-339.
11. Hantschel O., Rix U., Schmidt U. i wsp. The Btk tyrosine kinase is a major target of the Bcr-Abl inhibitor dasatinib. Proc. Natl. Acad. Sci. USA 2007; 104: 13283-13288.

12. Weichsel R., Dix C., Wooldridge L. i wsp. Profound inhibition of antigen-specific T-cell effector functions by dasatinib. Clin. Cancer Res. Off J Am. Assoc. Cancer Res. 2008; 14: 2484-2491.

13. Mustjoki S., Laurinolli T., Ekblom M. i wsp. Clonal large granular lymphocyte (LGL) expansion associated with dasatinib therapy. Blood 2007; 110: abstrakt 2938.

14. Bristol-Myers Squibb. Sprycel. Charakterystyka Produktu Leczniczego. 2014.

15. Deininger M., O'Brien S.G., Guilhot F. i wsp. International Randomized Study of Interferon Vs STI571 (IRIS) 8-year follow up: sustained survival and low risk for progression or events in patients with newly diagnosed chronic myeloid leukemia in chronic phase (CML-CP) treated with imatinib. Blood 2009; 114: abstrakt 1126.

16. Giles F.J., le Coutre P.D., Pinilla-Ibarz J. i wsp. Nilotinib in imatinib-resistant or imatinib-intolerant patients with chronic myeloid leukemia in chronic phase: 48-month follow-up results of a phase II study. Leukemia 2013; 27: 107-112.

17. Rollin J., Pouplard C., Gratacap M.-P. i wsp. Polymorphisms of protein tyrosine phosphatase CD148 influence Fc $\gamma$ RIIA-dependent platelet activation and the risk of heparin-induced thrombocytopenia. Blood 2012; 120: 1309-1316.

18. Mustjoki S., Ekblom M., Arstila T.P. i wsp. Clonal expansion of T/NK-cells during tyrosine kinase inhibitor dasatinib therapy. Leukemia 2009; 23: 1398-1405.

19. Kim D.H., Kamel-Reid S., Chang H. i wsp. Natural killer or natural killer/T cell lineage large granular lymphocytosis associated with dasatinib therapy for Philadelphia chromosome positive leukemia. Haematologica 2009; 94: 135-139.

20. Kreutzman A., Juvonen V., Kairisto V. i wsp. Mono/oligoclonal T and NK cells are common in chronic myeloid leukemia patients at diagnosis and expand during dasatinib therapy. Blood 2010; 116: 772-782.

21. Kreutzman A., Ladell K., Koechel C. i wsp. Expansion of highly differentiated CD8 + T-cells or NK-cells in patients treated with dasatinib is associated with cytomegalovirus reactivation. Leukemia 2011; 25: 1587-1597.

22. Powers J.J., Dubovsky J.A., Epling-Burnette P.K. i wsp. A molecular and functional analysis of large granular lymphocyte expansions in patients with chronic myelogenous leukemia treated with tyrosine kinase inhibitors. Leuk. Lymphoma 2011; 52: 668-679.

23. Mustjoki S., Kreutzman A., Dix C. i wsp. Large granular lymphocyte (LGL) expansions comprising oligoclonal T cell or NK cell populations in dasatinib treated patients are associated with HLA$-\mathrm{A} * 0201, \mathrm{CMV}$ reactivation and enhanced anti-leukemic control. Blood 2009; 114: abstrakt 1123.

24. Valent J.N., Schiffer C.A. Prevalence of large granular lymphocytosis in patients with chronic myelogenous leukemia (CML) treated with dasatinib. Leuk. Res. 2011; 35: e1-e3.

25. Lee S.J., Jung C.W., Kim D.-Y. i wsp. Retrospective multicenter study on the development of peripheral lymphocytosis following second-line dasatinib therapy for chronic myeloid leukemia. Am. J. Hematol. 2011; 86: 346-350.

26. Mustjoki S., Auvinen K., Kreutzman A. i wsp. Rapid mobilization of cytotoxic lymphocytes induced by dasatinib therapy. Leukemia 2013; 27: 914-924.

27. Matsushita M., Tonegawa K., Mori T. i wsp. Detection of leukemia associated antigen-specific cytotoxic $\mathrm{T}$ cells in a patient with Philadelphia chromosome-positive leukemia during treatment with dasatinib. Leuk. Lymphoma 2014; 55: 722-724. 